\title{
Identifikasi Zona Potensi Banjir Berbasis Sistem Informasi Geografis Menggunakan Metode Overlay dengan Scoring di Kabupaten Agam, Sumatera Barat
}

\author{
Ari Septian ${ }^{1 *}$, Annisa Yulia Elvarani ${ }^{1}$, Anisha Syafira Putri' ${ }^{1}$ Ikram Maulia1', Ledia Damayanti ${ }^{1}, \mathbf{M}$. \\ Zaki Pahlevi' ${ }^{1}$, Fatmawati Hajar Aswad ${ }^{2}$ \\ 1 Jurusan Teknik Geofisika, Fakultas Teknik, Universitas Lampung, Jl. Prof. Dr. Ir. Sumantri Brojonegoro, Bandar Lampung, \\ Lampung 35141 \\ ${ }^{2}$ Program Studi Perencanaan Wilayah dan Kota, Institut Teknologi Sumatera, Jl. Terusan Ryacudu, Desa Way Hui, Kecamatan Jati \\ Agung, Kabupaten Lampung Selatan
}

Dikirim:
10 April 2020
Direvisi:
28 April 2020
Diterima:
29 April 2020
*Email Korespondensi:
ariseptian345@gmail.com
20) (1) (2)

\begin{abstract}
Abstrak: Banjir merupakan suatu bencana alam yang selalu terjadi di banyak kota dalam skala yang berbeda di mana air dengan jumlah debit yang berlebih berada di daratan rendah yang kering. Berdasarkan hal ini dilakukan penelitian rawan banjir di Kabupaten Agam Sumatera Barat. Penelitian ini menggunakan data primer dan data sekunder berupa data topografi, kemiringan lereng, geologi dan jenis tanah, serta data curah hujan dan data penggunaan lahan. Penelitian ini dilakukan agar bisa mendapatkan tingkat kerawanan banjir dengan Sistem Informasi Geografis Pada penginderaan jauh menggunakan Analisis Weighted Scorring yang dapat diaplikasikan untuk mengidentifikasi potensi bencana banjir suatu daerah. Kabupaten Agam memiliki luas daerah 2.232,30 $\mathrm{Km}^{2}$ atau (5,29\%) dari luas total wilayah provinsi Sumatera Barat. Kabupaten Agam memiliki kondisi topografi yang bervariasi dan daerah ini merupakan daerah yang dikategorikan sebagai daerah yang rawan banjir dikarenakan memiliki intensitas ratarata hujan yang cukup tinggi pada wilayah timur, hal ini juga didukung dengan topografi daerah kabupaten Agam yang didominasi oleh daratan yang curam, dan sistem drainase yang buruk yaitu lebih dari 50\% wilayah Kabupaten Agam, Sumatera Barat. Lalu data tutupan lahan sawah dan juga pemukiman dengan curah hujan tahunan sebesar 3200 $3700 \mathrm{~mm} / \mathrm{thn}$, sehingga $<50 \%$ daerah ini berpotensi rawan banjir.

Kata kunci: banjir, data, intensitas, pembobotan, pemetaan, topografi
\end{abstract}

\begin{abstract}
Flooding is a natural disaster that always occurs in many cities on different scales where water with excessive discharge is in dry low land. Based on this research flood-prone research conducted in Agam Regency, West Sumatra. This study uses primary and secondary data in the form of topographic data, slope, geology and soil types, as well as rainfall and land use data. This research was conducted in order to get the level of flood vulnerability with Geographic Information Systems on remote sensing using Weighted Scorring Analysis which can be applied to identify potential flood disasters in an area. Agam Regency has an area of 2,232.30 $\mathrm{Km}^{2}$ or (5.29\%) of the total area of the province of West Sumatra. Agam Regency has varied topographic conditions and this area is categorized as a flood-prone area due to having a fairly high average rainfall intensity in the eastern region, this is also supported by the topography of the Agam regency area which is dominated by steep land, and poor drainage system, which is more than $50 \%$ of the Agam Regency, West Sumatra. Then data on land cover and settlements with annual rainfall of $3200-3700 \mathrm{~mm} / \mathrm{yr}$, so that $<50 \%$ of this area is potentially prone to flooding.

Keywords: data, flood, intensity, mapping, topography, weighting
\end{abstract}

\section{PENDAHULUAN}

Banjir merupakan suatu bencana alam yang selalu terjadi di banyak kota dalam skala yang berbeda-beda di mana air dengan jumlah debit yang berlebih berada di daratan rendah yang kering. Banjir ini terjadi karena faktor manusia dan faktor alam. Faktor fisik serta faktor fisik pada daerah alir sungai (DAS) adalah faktor alam dan saling terkait dalam kejadian banjir. Adapun faktor iklim yang terkait dengan banjir yaitu adalah hujan, di mana hujan merupakan sumber air dari kehidupan manusia dan jika hujan yang turun kebumi secara berlebihan dapat menyebabkan banjir. Sedangkan faktor fisik dari DAS yang sangat mempengaruhi terjadinya banjir adalah kemampuan tanah dalam meresapkan air hujan, faktor lereng serta jarak dari badan air. Wilayah yang lebih rentan terhadap genangan air, antara lain wilayah dekat dengan sungai yang datar, dan wilayah yang memiliki drainase buruk. Faktor aktivitas manusia dalam menggunakan lahan juga mempengaruhi kondisi fisik DAS sehingga berpengaruh terhadap kejadian banjir. Kabupaten Agam merupakan salah satu daerah di Sumatera Barat yang bermasalah dengan banjir, Wakil Bupati Kabupaten Agam, Sumatera Barat Trinda Farhan Satria mengatakan bahwa didaerahnya terdapat lima kecamatan yang masuk kategori rawan bencana banjir bandang dan tanah longsor yakni kecamatan Empat Koto, Kecamatan Malalak, kecamatan Tanjung Raya, Kecamatan Palupuah, dan kecamatan Palembayan. Menurut Trindater, letak pada daerah di punggung bukit barisan, SIG serta penginderaan jauh dapat diaplikasikan untuk mengidentifikasi potensi banjir suatu wilayah.

Penginderaan Jauh memudahkan dalam perolehan informasi yang ada di lapangan tanpa harus langsung berinteraksi dengan objek. Umumnya SIG (Sistem Informasi Geografis) dapat dengan cepat, mengidentifikasi kerentanan banjir suatu wilayah dengan menggunakan pemodelan kartografi ter- 
hadap faktor-faktor penyebab/ parameter dari banjir.

\section{TINJAUAN PUSTAKA}

\subsection{BANJIR}

Bencana adalah suatu peristiwa yang dapat membahayakan, mengancam dan mengganggu kehidupan manusia yang dapat disebabkan oleh faktor alam ataupun karena faktor manusia sehingga dapat mengakibatkan timbulnya kerusakan lingkungan, trauma (dampak psikologis), korban jiwa dan kerugian harta benda. (Perka BNPB No. 02 Tahun 2012).

Banjir merupakan sebuah bencana alam yang sering terjadi pada suatu daerah dengan skala yang berbeda, di mana air dengan jumlah yang berlebih berada pada suatu daratan yang kering. Banjir dapat menyebabkan kerusakan yang parah, terlebih pada daerah yang mempunyai kepadatan penduduk yang tinggi seperti pada daerah yang terletak di bantaran sungai atau daerah-daerah yang terkena banjir secara periodik atau berkala. Banjir dapat dibagi menjadi dua kategori, yaitu 1) proses meluapnya air sungai yang disebabkan oleh debit air sungai yang melebihi daya tampung sungai tersebut pada saat keadaan dengan curah hujan yang tinggi, dan 2) genangan air pada daerah dataran rendah yang datar yang biasanya tidak tergenang oleh air dalam jumlah yang cukup besar. (Suprapto, 2011)

Terdapat beberapa jenis-jenis banjir yang disebabkan karena beberapa faktor, di antaranya yaitu, Banjir air yang merupakan banjir yang umumnya sering terjadi pada saat hujan dengan intensitas yang tinggi. Penyebab banjir air dapat disebabkan karena meluapnya air di danau, sungai, selokan, ataupun aliran air yang lainnya sehingga menyebabkan air tersebut naik dan menggenangi suatu daratan. Banjir bandang merupakan banjir yang tidak hanya mengangkut air melainkan juga membawa material lumpur. Banjir bandang ini sangat berbahaya dibandingkan dengan banjir air umumnya. Banjir lumpur merupakan banjir yang seperti banjir bandang namun lumpur tersebut berasal dari dalam bumi sehingga dapat menggenangi suatu daratan. Banjir rob adalah banjir yang disebabkan karena adanya pasang air laut. Banjir rob ini pada umumnya melanda daerah yang berada dekat dengan bibir pantai. Banjir Cileunang ialah suatu banjir yang mirip dengan banjir air biasa akan tetapi banjir ini disebabkan karena intensitas hujan yang sangat tinggi dan mempunyai debit air dengan jumlah yang banyak sehingga dapat menggenangi daratan. Banjir lahar merupakan banjir yang disebabkan karena lahar gunung berapi masih aktif saat meletus ataupun pada saat mengalami erupsi.

Banjir adalah proses meluapnya air di mana kapasitas sungai tidak dapat menampung jumlah air tersebut, sehingga melebihi batas tinggi muka air dan menyebabkan air meluap dari sisi-sisi sungai yang mengakibatkan genangan pada daerah- daerah dataran rendah yang berada di sisi sungai, (Nurjanah, dkk., 2012) Umumnya banjir ini disebabkan karena intensitas curah hujan yang tinggi, akibatnya sistem pengaliran air seperti sungai, anak sungai, sistem saluran drainase dan kanal penampang banjir tidak mampu menampang jumlah akumulasi air hujan sehingga air tersebut meluap. Kemampuan/daya tampung sistem pengaliran air ini tidak selamanya sama, hal ini dapat terjadi karena adanya perubahan seperti akibat sedimentasi pada sungai, penyempitan sungai karena ulah manusia, adanya sumbatan sampah dan banyak faktor lainnya.

Adapun faktor yang dapat menyebabkan timbulnya banjir yaitu karena kurangnya pengetahuan serta, kesiapan dalam memanajemen bencana. Maka dari pengetahuan mitigasi/pencegahan bencana banjir sangat diperlukan untuk menambah pengetahuan masyarakat dan sebagai informasi dalam penanggulangan bencana guna untuk mengurangi dampak kerusakan yang dapat disebabkan oleh bencana banjir. Dampak banjir ini tidak hanya berdampak terhadap kerugian materi dan nyawa saja, tetapi juga dapat berdampak pada perekonomian masyarakat seperti tergenangnya lahan pertanian, perkebunan dan juga sarana prasarana yang menjadi penunjang perekonomian pada daerah yang terdampak banjir daerah. Pemberdayaan masyarakat adalah salah kegiatan yang dilakukan untuk meningkatkan pemahaman masyarakat agar dapat melaksanakan mitigasi bencana baik sebelum ataupun sesudah bencana tersebut terjadi (Santosa, 2015).

\subsection{TOPOGRAFI KAWASAN RAWAN BANJIR}

Menurut Suprapto (2011:35) potensi bencana banjir di wilayah Indonesia sangat besar, hal ini disebabkan karena wilayah Indonesia sebagian besar adalah lautan, banyak daerah bertopografi dataran rendah, serta memiliki banyak cekungan. Curah hujan tinggi yang terjadi di daerah hulu dapat menyebabkan bencana banjir di daerah hilir terutama daerah-daerah yang tinggi permukaan tanahnya lebih rendah atau sama dengan tinggi rata-rata permukaan air laut.

Sementara untuk banjir yang diakibatkan karena adanya aktivitas manusia seperti perubahan kondisi dari daerah aliran sungai (DAS), kawasan pemukiman di sekitar bantaran, rusaknya drainase, vegetasi alami, kerusakan bangunan pengendali banjir, dan perencanaan sistem pengendali banjir yang tidak tepat. Daerah Aliran Sungai (DAS) merupakan suatu daerah aliran sungai yang mana dibatasi oleh punggung gunung/pegunungan di mana air hujan yang jatuh di daerah tersebut akan mengalir dan menuju sungai utama pada suatu titik/stasiun. (BNBP, 2012).

Luas DAS (Daerah Aliran Sungai) dapat diketahui dengan melakukan pengukur daerah pada peta topografi. Luas DAS sangat berpengaruh terhadap debit sungai (volume sungai). Biasanya semakin besar DAS semakin besar juga jumlah limpasan dari permukaan sehingga semakin besar 
pula aliran permukaan atau debit sungai tersebut. (Triatmodjo, 2009)

\section{a. Daerah Pesisir Pantai}

Daerah pesisir pantai merupakan daerah dengan tingkat rawan banjir yang tinggi. Hal itu dikarenakan daerah pesisir pantai merupakan daerah dataran rendah yang memiliki rata-rata ketinggian permukaan tanahnya lebih rendah atau sama dengan rata-rata ketinggian air laut (mean sea level / MSL). Daerah dengan topografi ini biasanya lebih sering dilanda oleh banjir rob, yang disebabkan oleh pasangnya air laut yang disebabkan oleh pengaruh gravitasi dari bulan ataupun matahari sehingga rata-rata ketinggian air laut lebih tinggi daripada ketinggian rata-rata daerah dataran rendah.

\section{b. Daerah Dataran Banjir}

Daerah dataran banjir merupakan daerah yang terbentuk akibat adanya proses pengendapan (sedimentasi) banjir. Hal ini menyebabkan aliran air yang akan menuju sungai terhambat, sehingga daerah tersebut rawan terhadap banjir baik yang disebabkan oleh luapan air sungai ataupun karena curah hujan yang tinggi pada daerah tersebut. Bencana banjir ini umumnya terjadi pada daerah yang dilewati oleh aliran sungai besar dengan debit air yang banyak.

\section{c. Daerah Sempadan Sungai}

Daerah ini merupakan salah satu daerah rawan banjir, karena berada sepanjang tepi aliran sungai baik itu sungai yang terbentuk karena proses alam maupun sungai buatan. Daerah sempadan ini banyak dimanfaatkan sebagai tempat tinggal dan tempat-tempat untuk kegiatan usaha, sehingga masyarakat daerah ini bisa terkena dampak buruk jika terjadi banjir.

\section{d. Daerah Cekungan}

Daerah cekungan merupakan daerah yang memiliki lingkup yang cukup luas baik yang ada pada dataran rendah ataupun di dataran tinggi. Daerah cekungan ini dapat menjadi daerah yang rawan bencana banjir apabila dalam area tersebut tidak mempunyai penataan Kawasan yang baik atau sistem drainase pada daerah tersebut buruk sehingga air dapat menggenangi daerah tersebut.

\subsection{PENGINDERAAN JAUH}

Adapun pengertian pengindraan jauh merupakan pengukuran atau akuisisi data yaitu dari sebuah objek, atau merupakan fenomena pada sebuah alat yang tidak secara fisik melakukan kontak dengan suatu objek. Kemudian, data pada Penginderaan Jauh yaitu berupa citra, grafik, serta data numerik. Selanjutnya data tersebut dianalisis sehingga didapatkan informasi mengenai daerah, objek, dan fenomena-fenomena yang diindera atau diteliti.

Pada analisis data penginderaan jauh juga memerlukan data rujukan yaitu berupa data statistik, peta tematik, dan data lapangan. Hasil analisis yang diperoleh yaitu informasi tentang bentang lahan, jenis penutup lahan, kondisi lokasi, serta kondisi sumber daya daerah yang diindera (Aditya, 2010). Pada jenis penutupan lahan adalah para-meter fisik yang dapat membantu analisa serta evaluasi dalam aplikasi penginderaan jauh. Dengan menggunakan data Penginderaan Jauh yang dapat menghemat waktu dan biaya kita akan mendapatkan data penutupan lahan. Salah satu contoh pada bentuk data Penginderaan Jauh yaitu citra satelit. Citra dari satelit Landsat yaitu salah satu citra satelit yang dapat digunakan dalam aplikasi Penginderaan Jauh karena dalam interpretasi penutupan lahan daerah yang luas cukup baik serta mudah didapatkan (Nugraha, 2013). Citra Landsat terdiri dari beberapa saluran yang memiliki kegunaan tertentu yang dapat dilihat pada Tabel 1.

Tabel 1. Kisaran panjang gelombang citra Landsat beserta kegunaan utamanya

\begin{tabular}{|c|c|c|}
\hline Saluran & $\begin{array}{l}\text { Kisaran Panjang } \\
\text { Gelombang }\end{array}$ & Kegunaan Utama \\
\hline 1 & $\begin{array}{l}\text { 0,45-0,52 merupakan } \\
\text { Gelombang Biru }\end{array}$ & $\begin{array}{l}\text { Pembedaan vegetasi serta Lahan, kemudian penetrasi tubuh } \\
\text { air. }\end{array}$ \\
\hline 2 & $\begin{array}{l}\text { 0,52-0,60 merupakan } \\
\text { Gelombang Hijau }\end{array}$ & $\begin{array}{l}\text { Pengamatan pada puncak pantulan vegetasi pada saluran hijau } \\
\text { pada dua saluran penyerapan. Pengamatan yang dimaksudkan } \\
\text { untuk membedakan jenis vegetasi, serta membedakan tanaman } \\
\text { sehat dan tidak sehat }\end{array}$ \\
\hline 3 & $\begin{array}{l}\text { 0,63-0,69 merupakan } \\
\text { Gelombang Merah }\end{array}$ & $\begin{array}{l}\text { Saluran terpenting yang digunakan untuk membedakan jenis } \\
\text { vegetasi. Digunakan sebagai pembeda antara lahan terbuka } \\
\text { terhadap lahan bervegetasi dan berada pada daerah } \\
\text { penyerapan klorofil. }\end{array}$ \\
\hline 4 & $\begin{array}{l}\text { 0,76-0,90 merupakan } \\
\text { Gelombang } \\
\text { Inframerah Dekat }\end{array}$ & $\begin{array}{l}\text { Saluran peka yaitu terhadap biomassa vegetasi. Kemudian } \\
\text { untuk identifikasi jenis tanaman, serta memudahkan pembedaan } \\
\text { tanah. }\end{array}$ \\
\hline 5 & $\begin{array}{l}\text { 1,55- } 1,75 \text { merupakan } \\
\text { Gelombang } \\
\text { Inframerah Pendek }\end{array}$ & $\begin{array}{l}\text { Saluran penting untuk penentuan jenis tanaman, dan juga } \\
\text { digunakan untuk kandungan air tanaman. }\end{array}$ \\
\hline
\end{tabular}




\begin{tabular}{|c|c|c|}
\hline Saluran & $\begin{array}{l}\text { Kisaran Panjang } \\
\text { Gelombang }\end{array}$ & Kegunaan Utama \\
\hline 6 & $\begin{array}{l}\text { 10,40-12,50 } \\
\text { merupakan } \\
\text { Gelombang } \\
\text { Inframerah Termal }\end{array}$ & $\begin{array}{l}\text { Pada analisis gangguan vegetasi, pemisahan kelembaban } \\
\text { tanah, klasifikasi vegetasi, dan gejala lainnya yang berhubungan } \\
\text { dengan panas. }\end{array}$ \\
\hline 7 & $\begin{array}{l}\text { 2,085-2,35 merupakan } \\
\text { Inframerah Pendek }\end{array}$ & $\begin{array}{l}\text { Membedakan pada formasi batuan dengan pemetaan } \\
\text { hidrotermal }\end{array}$ \\
\hline 8 & $\begin{array}{l}0,50-0,90 \text { merupakan } \\
\text { Pankromatis }\end{array}$ & Meningkatkan resolusi spasial \\
\hline
\end{tabular}

\section{BAHAN DAN METODE PENELITIAN}

\subsection{Waktu dan Lokasi Penelitian}

Lokasi penelitian ini berada di Kabupaten Agam, Sumatera Barat sebagaimana terlampir pada Gambar 1. Penelitian yang kami lakukan dimulai dari bulan Februari 2019 sampai dengan bulan Desember 2019 di Laboratorium Geofisika Mitigasi Bencana Geologi, Jurusan Teknik Geofisika, Fakultas Teknik, Universitas Lampung.

\subsection{Alat dan Bahan}

Peralatan yang digunakan dalam penelitian ini adalah seperangkat laptop dan software. Software yang digunakan dalam pengolahan data tersebut adalah ArcGIS versi 10.3. dalam pengolahan data ini kami menggunakan beberapa bahan yaitu data peta administrasi wilayah Kabupaten Agam yang terletak di Sumatera bagian barat, lalu ada data DEM SRTM dan juga data curah hujan.
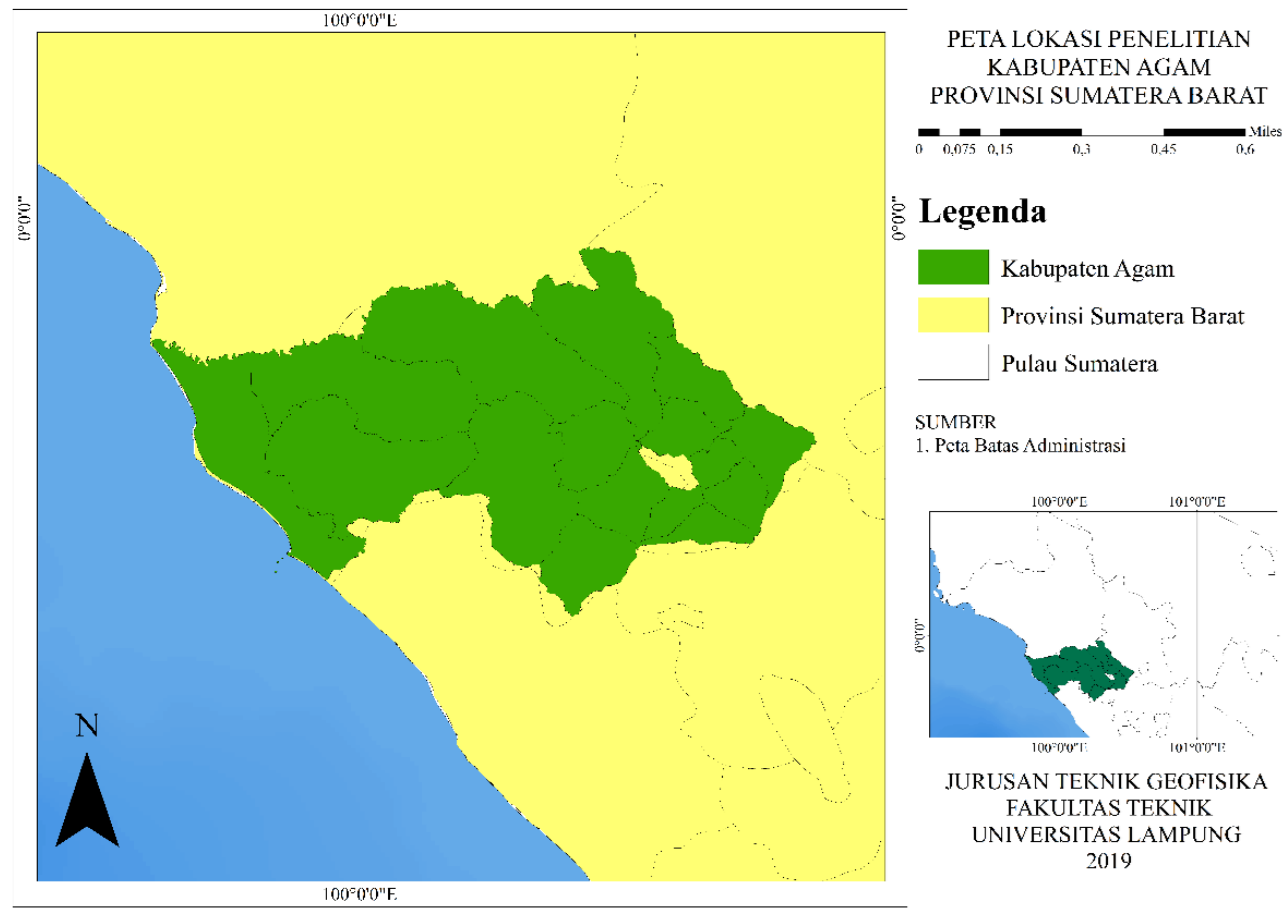

Legenda

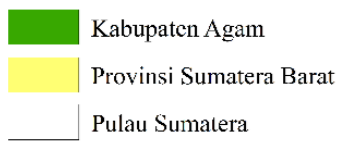

SUMBTR

1. Peta Batas $\Lambda$ dministrasi

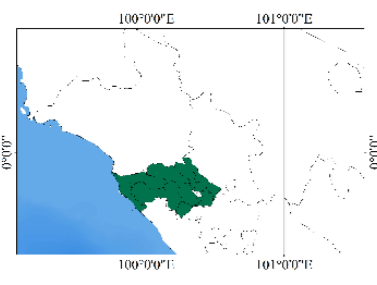

JURUSAN TEKNIK GEOFISIKA

FAKULTAS TEKNIK

UNIVERSITAS LAMPUNG

2019

Gambar 1. Peta lokasi penelitian yang menunjukkan daerah Kabupaten Agam, Sumatera Barat.

\subsection{Metodologi Penelitian}

Metodologi yang kami gunakan dalam pengolahan data yaitu metode analisis spasial, di mana menurut Paundra Ksatria Wahyutomo, dkk., (2016) metode ini merupakan metode yang dapat digunakan dalam melakukan pengolahan data-data Sistem Informasi Geografi untuk meneliti dan mengeksplorasi dari sudut pandang keruangan. Analisis spasial data SIG yang kami gunakan menggunakan pendekatan secara kualitatif maupun kuantitatif.

1. Metode Kualitatif

Metode ini menggunakan data spasial dengan klasifikasi data yang sifatnya kualitatif.

2. Metode Kuantitatif

Metode Kuantitatif ini terbagi menjadi 3 tahap: a. Metode Kuantitatif Binary yaitu: pendekatan dengan metode ini menggunakan fungsi logika AND pada algoritma.

b. Metode Kuantitatif Berjenjang yaitu: pendekatan dengan metode ini akan menghasilkan nilai yang sama untuk setiap komponen yang dianalisis dan tetap terdapat faktor pembatas untuk setiap parameternya.

c. Metode Kuantitatif Berjenjang Tertimbang yaitu: pendekatan dengan metode ini memberikan nilai pengharkatan, namun dengan bobot yang berbeda untuk setiap variabel yang dianalisis. Pembobotan ini didasarkan besar atau kecilnya pengaruh variabel tersebut. Di mana setiap variabel pengaruhnya akan berbeda tergantung dari analisis yang dilakukan pada objek tersebut. 
Proses pengolahan data pada penelitian ini dilakukan dengan beberapa tahapan:

1. Tahap Persiapan data

Pada tahapan ini, data yang dipersiapkan berupa data peta administrasi wilayah Kabupaten Agam, data DEM SRTM dan data curah hujan.

2. Tahap Pengolahan data

a. Koreksi Geometrik

Pada koreksi ini diperhitungkan untuk mereduksi kesalahan geometrik pada data

b. Koreksi radiometrik Citra Satelit

Koreksi ini dilakukan dengan mengalibrasi radiometrik dan koreksi atmosfer.

$$
\rho_{\lambda}{ }^{\prime}=M \rho^{*} Q_{c a l}+A_{\rho}
$$

Di mana

$\rho_{\lambda}{ }^{\prime} \quad$ : TOA planetary spectral reflectance

$M \rho \quad$ : Reflectance multiplicative band

$Q_{\text {cal }} \quad:$ L1 pixel value in DN

$A_{\rho} \quad:$ Refletance additive band

\section{c. Pembuatan Peta Ketinggian}

Peta ini dibuat dengan memotong citra untuk membatasi daerah penelitian dan mengklasifikasikannya berdasarkan ketinggian dataran. Semakin rendah maka akan semakin berpotensi untuk terjadinya banjir.

d. Peta kemiringan lahan

Peta ini dibuat dengan menggunakan peta DEM SRTM dan dilakukan pemotongan citra untuk membatasi daerah penelitian lalu dibuat slope. Kemudian hasilnya diklasifikasikan berdasarkan batasan nilai untuk mendapatkan kelas lereng dari daerah penelitian.

e. Peta drainase

Peta ini dibuat dengan memotong citra untuk membatasi daerah penelitian dan didasarkan pada jenis tanah di daerah penelitian sehingga selanjutnya dilakukan klasifikasi drainase. Peta ini dibuat dengan menggunakan metode NDVI. Menurut Andini dkk., (2018) metode NDVI merupakan suatu metode yang digunakan untuk mengetahui kerapatan dari vegetasi, indeks kehijauan maupun aktivitas fotosintesis vegetasi.

$$
N D V I=\frac{(N I R-V I S)}{N I R+V I S} ; N D V I=\frac{(N I R-R E D)}{N I R+R E D}
$$

Di mana:

NIR : Gelombang inframerah dekat

$R E D$ : Gelombang merah

Setelah mendapatkan nilai NDVI, lalu lakukan penurunan NDVI untuk mendapatkan proporsi vegetasi agar mendapatkan nilai emisivitas.

$$
P V=\left(\frac{N D V I-N D V I_{\min }}{N D V I_{\max }-N D V I_{\min }}\right)^{2}
$$

Di mana:

$$
\text { PV : Proporsi vegetasi }
$$

$N D V I_{\min }:$ Nilai NDVI terendah

$N V D I_{\text {max }}$ : Nilai NDVI tertinggi

f. Buffer Sungai

Peta ini dibuat dengan memotong citra untuk membatasi daerah penelitian dan didasarkan pada sistem drainase yang ada di daerah penelitian.

$$
D d=\frac{\sum L n}{A}
$$

Di mana:

Dd : kerapatan aliran

Ln : panjang sungai

A : Luas DAS

\section{g. Peta Curah Hujan}

Melakukan penajaman citra dengan memotong citra untuk membatasi daerah penelitian sehingga hanya didapatkan lokasi Kecamatan Agam, Sumatera Barat dan mengklasifikasikan peta curah hujan. Dapat dibuat dengan menggunakan 2 metode:

1. Metode Thiessen Polygon

Menurut Jauhari Pangaribuan, dkk. (2019) metode ini digunakan untuk menghitung bobot dari tiap stasiun yang mewakili luasan di sekitarnya.

$$
P=\frac{A_{1} P_{1}+A_{2} P_{2}+\cdots+A_{n} P_{n}}{A_{1}+A_{2}+\cdots+A_{n}}
$$

2. Metode Isohyet

Metode ini merupakan garis yang menghubungkan titik-titik dengan kedalaman hujan yang sama.

$$
P=\frac{A_{1}\left(\frac{P_{1}+P_{2}}{2}\right)+A_{2}\left(\frac{P_{1}+P_{2}}{2}\right)+\cdots+A_{n}\left(\frac{P_{n}+P_{n+1}}{2}\right)}{A_{1}+A_{2}+\cdots+A_{n}}
$$

h. Peta Tutupan Lahan

Melakukan pemotongan citra untuk membatasi daerah penelitian dan mengklasifikasikan peta tutupan lahan.

i. Analisis Atribut

1. Penskoran data

Penskoran tiap kelas disesuaikan dengan klasifikasi masing-masing parameter yang telah dibuat

2. Pembobotan

Pembobotan ini disesuaikan berdasarkan masing-masing pengaruh tiap parameter terhadap kejadian banjir.

j. Analisa AHP

Pada analis ini digunakan untuk menentukan tingkat prioritas dari parameter-parameter yang dipakai dalam pembuatan daerah rawan banjir.

$$
Z=C H+K M+T L
$$

Di mana:

$Z \quad$ : Jumlah total nilai rawan banjir

$\mathrm{CH}$ : Curah hujan

$K M$ : Kemiringan lereng

$T L$ : Tutupan lahan 


\section{k. Overlay}

Tahap ini dilakukan dengan menggabungkan parameter yang telah ditentukan beserta dengan atributnya sehingga didapatkanlah peta rawan banjir.

\section{KONDISI UMUM WILAYAH PENELITIAN}

Daerah penelitian yang kami amati adalah Wilayah kabupaten Agam, Sumatera Barat yang secara geografis berada pada garis 000 01' 34 " 000 28' 43" LS dan 990 46' 39" - 1000 32' 50" BT. Kabupaten ini memiliki luas daerah yang cukup besar dengan luas $2.232,30 \mathrm{~km}^{2}$. Di mana pada wilayah Batang Antokan di bagian selatan dan wilayah Batang Agam di bagian utara dari kabupaten ini dilalui oleh wilayah jalur pegunungan yang terbentuk dari dua jalur basin. Terdapat dua pulau yang berada di Kabupaten Agam dengan luasan daerah sekitar $1 \mathrm{~km}^{2}$ yaitu Pulau Tangah dan pulau Ujung.

Garis pantai Kabupaten Agam terhampar sepanjang $43 \mathrm{Km}$ dan terdapat pula sungai berukuran kecil yang mengalir dan bermuara di samudera Hindia seperti Batang Agam dan Batang Antokan. Terdapat 2 gunung yang menjulang tinggi yang ter-
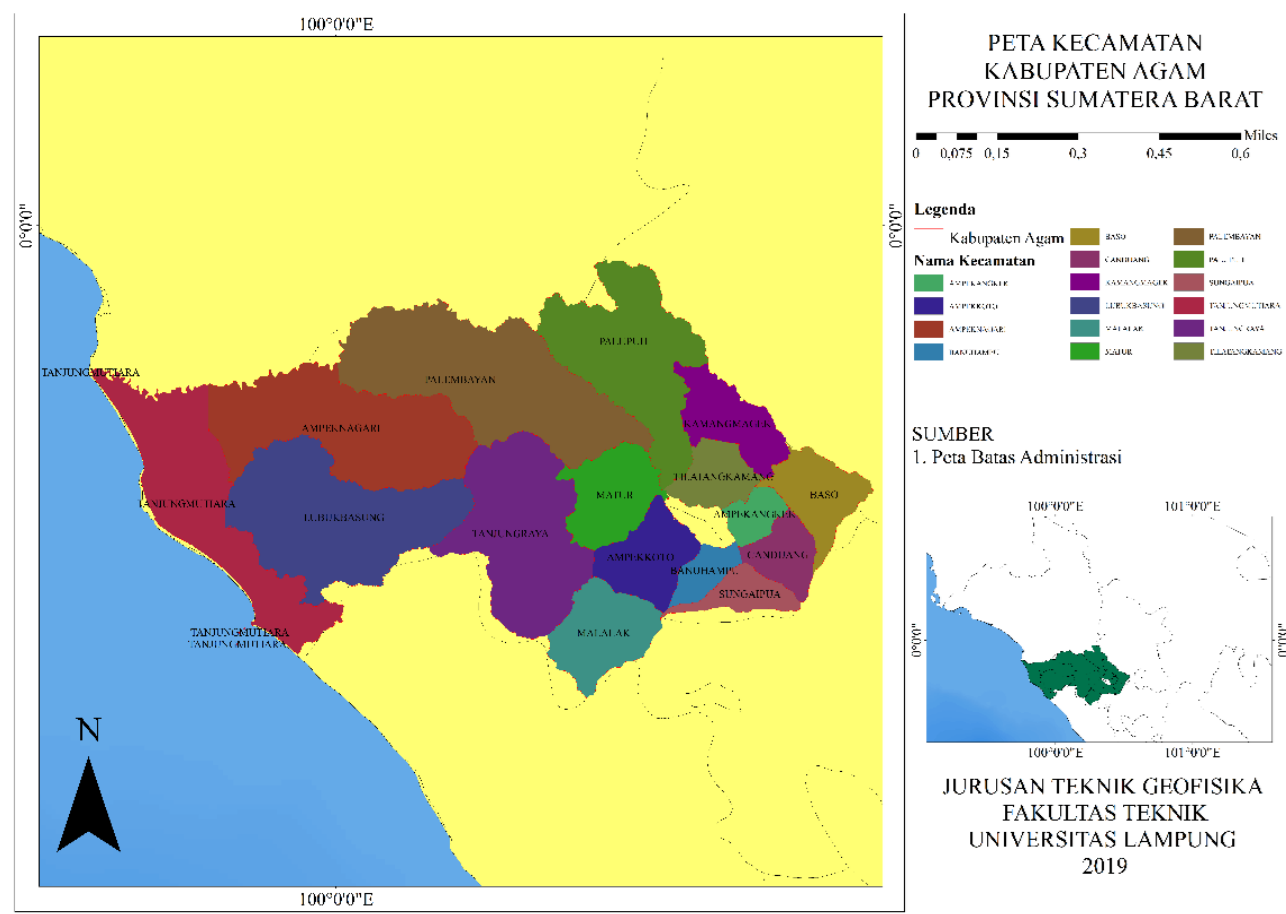

Gambar 2. Peta Kecamatan di Kabupaten Agam ini menggambarkan sebaran kecamatan di wilayah Kabupaten Agam yang terdiri dari 16 Kecamatan

letak di kecamatan Banuhampu yaitu Gunung Marapi dengan tinggi 2.891 meter dan Gunung Singgalang dengan tinggi 2.877 meter yang terletak di kecamatan IV Koto. Selain itu, terdapat pula danau Maninjau yang membentang seluas 9,95 m di Kecamatan Tanjung Raya. Ada 16 kecamatan yang tersebar di seluruh wilayah Kabupaten Agam.

\subsection{Topografi}

Kondisi topografi yang terbentang di Kabupaten Agam cukup bervariasi, mulai dari dataran rendah hingga dataran tinggi yang ketinggiannya berkisar antara 0 - 2.891 meter di atas permukaan laut. $\mathrm{Di}$ dalam topografi ini terdapat dua informasi yaitu tentang ketinggian dan kemiringan lereng di daerah tersebut.
Untuk mendapatkan kedua informasi tersebut, dibutuhkanlah data DEM SRTM dari daerah Agam, lalu dilakukanlah pengolahan data dengan bantuan software ArcGIS untuk mendapatkan informasi mengenai ketinggian dan kemiringan pada wilayah ini. Secara umum wilayah Kabupaten Agam terbagi menjadi 3 daerah ketinggian. Yang pertama berada pada ketinggian dari $0-500 \mathrm{mdpl}$ dengan luas sebesar $44,55 \%$ yang sebagian besar berada di wilayah barat. Lalu daerah dengan ketinggian dari $500-1000$ mdpl dengan luas sebesar $43,49 \%$ dan daerah yang berada pada ketinggian di atas $>1000$ mdpl dengan luas sebesar $11,96 \%$. Dalam pembuatan peta ini kami mengklasifikasikan ketinggian tersebut menjadi enam kelas yaitu dari 0 $>100$ mdpl. 


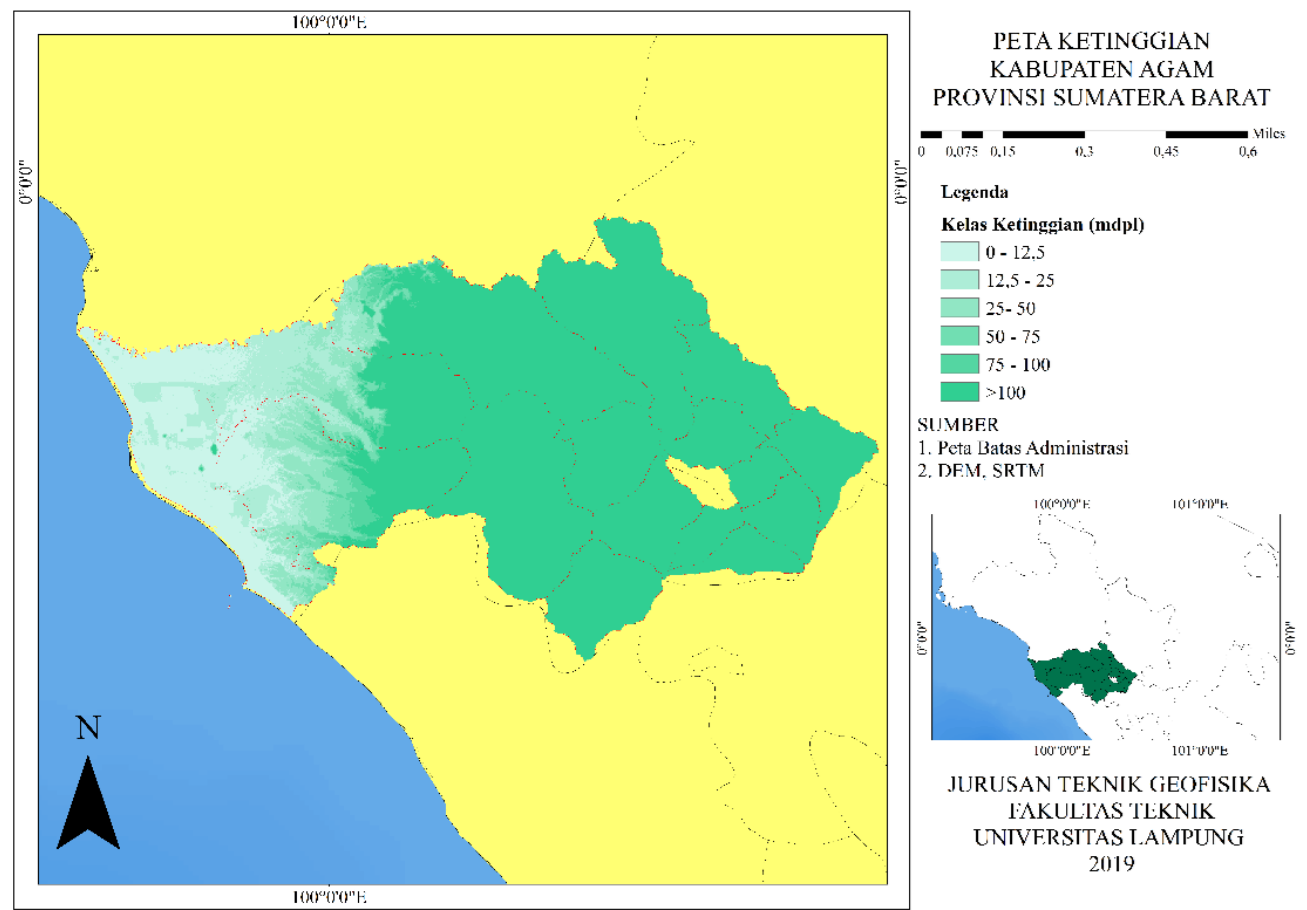

Gambar 3. Peta Kelas Ketinggian di Kabupaten Agam dikelompokkan menjadi enam kelas dari daerah rendah hingga tinggi.

Kabupaten Agam dalam pengklasifikasiannya kami bagi menjadi lima kelas lereng dengan pembagian yaitu daerah datar, datar dan berombak, bergelombang, daerah berbukit kecil, dan daerah berbukit besar. Daerah dengan kemiringan yang cenderung landai $(0-8 \%)$ berada di Kawasan sebelah barat yang membentang seluas 71.956 ha.
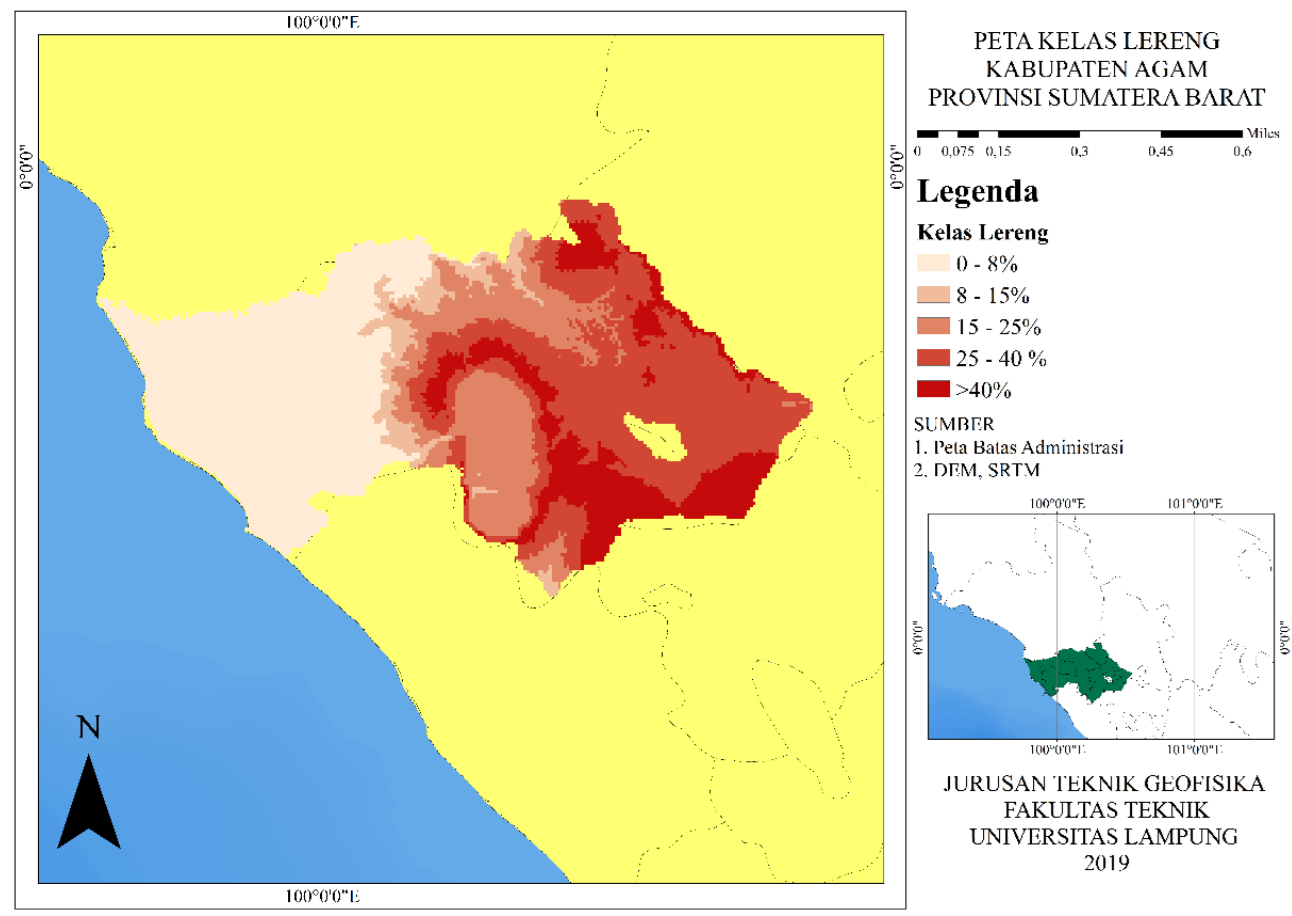

Gambar 4. Peta Kelas Lereng di Kabupaten Agam dikelompokkan menjadi lima kelas lereng dari daerah datar hingga daerah berbukit besar.

\subsection{Drainase}

Drainase Kabupaten Agam dikelompokkan menjadi empat kelas yang secara umum dijelaskan dengan kondisi sangat buruk, buruk, sedang, atau baik. Untuk ukuran sangat buruk memiliki persentase sekitar $20 \%$, lalu untuk buruk sekitar 47 $\%$, untuk parameter sedang sebesar $21 \%$, dan yang untuk baik sekitar $12 \%$. 

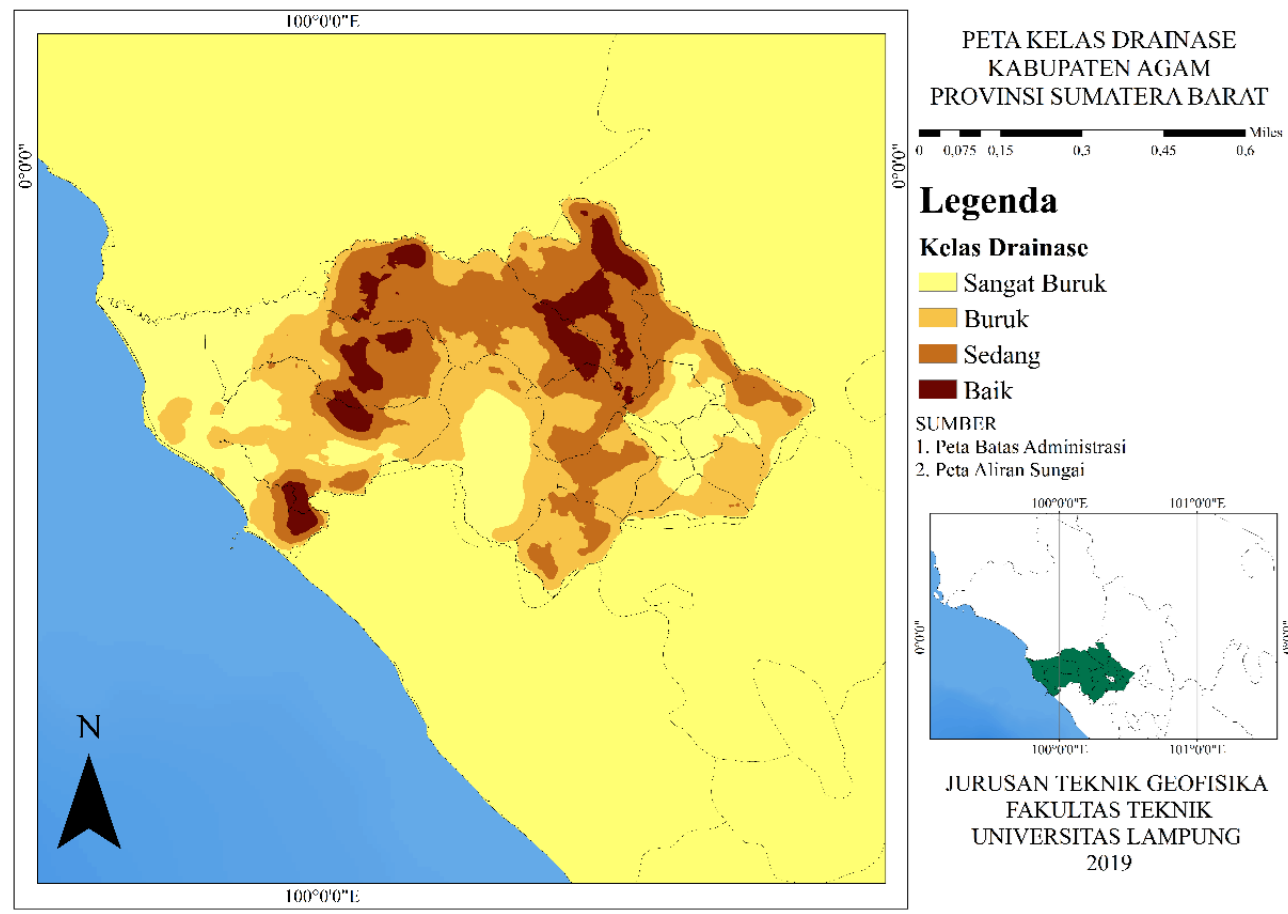

Gambar 5. Peta Kelas Drainase di Kabupaten Agam dikelompokkan menjadi empat kelas dari sangat buruk, buruk, sedang, dan baik.

\subsection{Analisis Peta Tematik}

Untuk mendapatkan peta kelas drainase tanah maka digunakanlah peta tanah. Di mana peta kelas drainase tanah didapatkan dengan melakukan pendekatan kemampuan drainase tanah yang didasarkan pada informasi tekstur tanah dari jenis tanah yang ada di daerah penelitian yang berbentuk lembaran kertas.

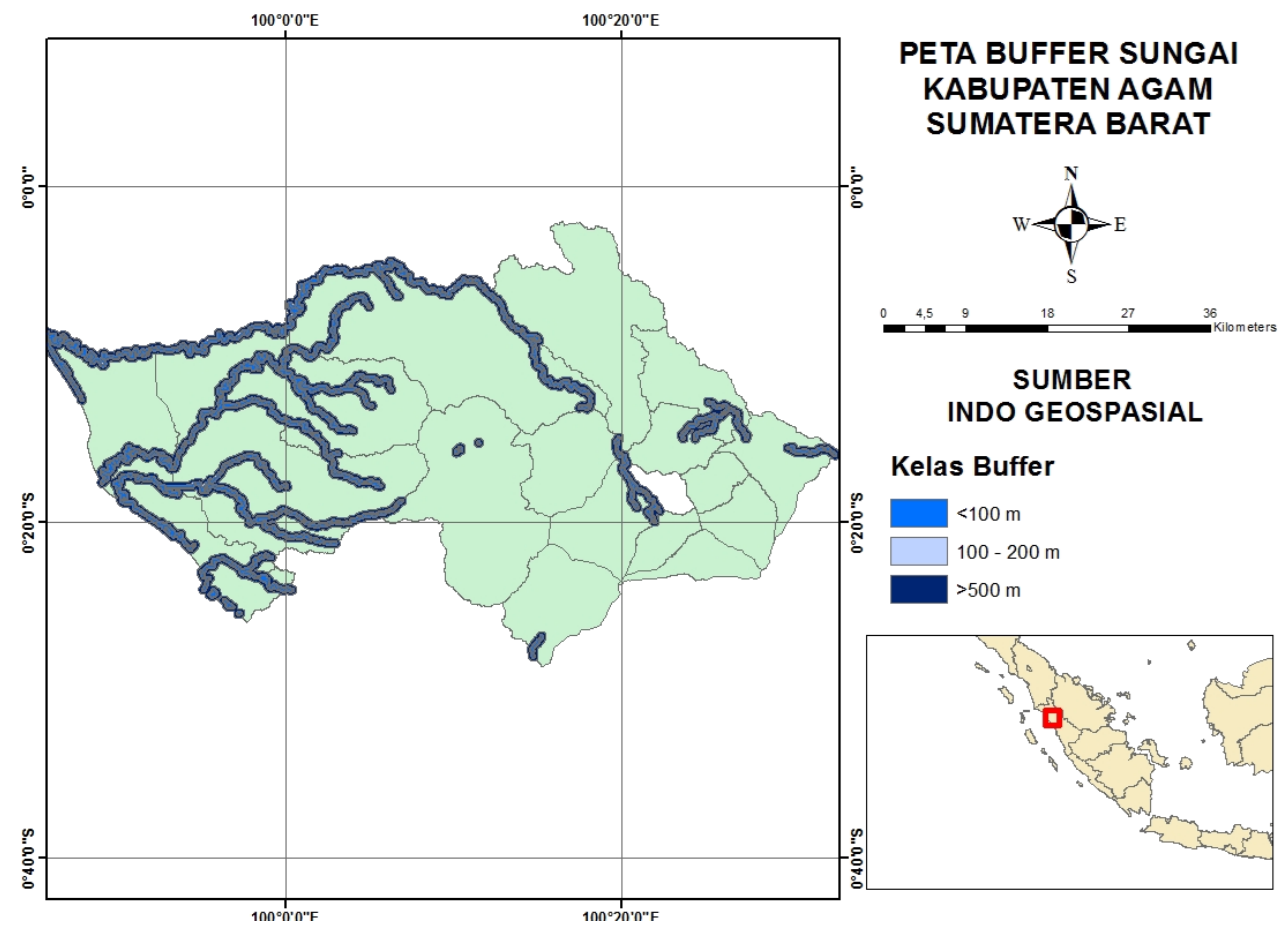

Gambar 6. Peta Buffer Sungai di Kabupaten agam terbagi menjadi tiga kelompok kelas dari kedalaman kurang dari $100 \mathrm{~m}$ hingga lebih dari $500 \mathrm{~m}$.

\subsection{Bentuk Lahan}

Kabupaten Agam memiliki 3 bentuk lahan yang didominasi oleh dataran. Berdasarkan Sistem Wilayah Sungai yang terdapat di Kabupaten Agam, wilayah ini mempunyai 3 (tiga) Sistem Wilayah
Sungai yaitu: Sistem Wilayah Sungai Masang Pasaman Sistem Wilayah Sungai Arau, Kuranji, Anai, Mangau, Antokan dan Akuaman, serta Sistem Wilayah Sungai Indragiri. Berdasarkan data Daerah Aliran Sungai (DAS)yang ada di Kabupaten Agam, Available online at https://jgrs.eng.unila.ac.id/ DOI: https://doi.org/10.23960/igrs.2020.v1i1.25 
terdapat 8 (delapan) Daerah Aliran Sungai yang terdiri dari DAS Andaman, DAS Masang Kiri, DAS Masang Kanan, DAS Mangau, DAS Batang Tiku
DAS Batang Naras, DAS Antokan serta DAS Kuantan.

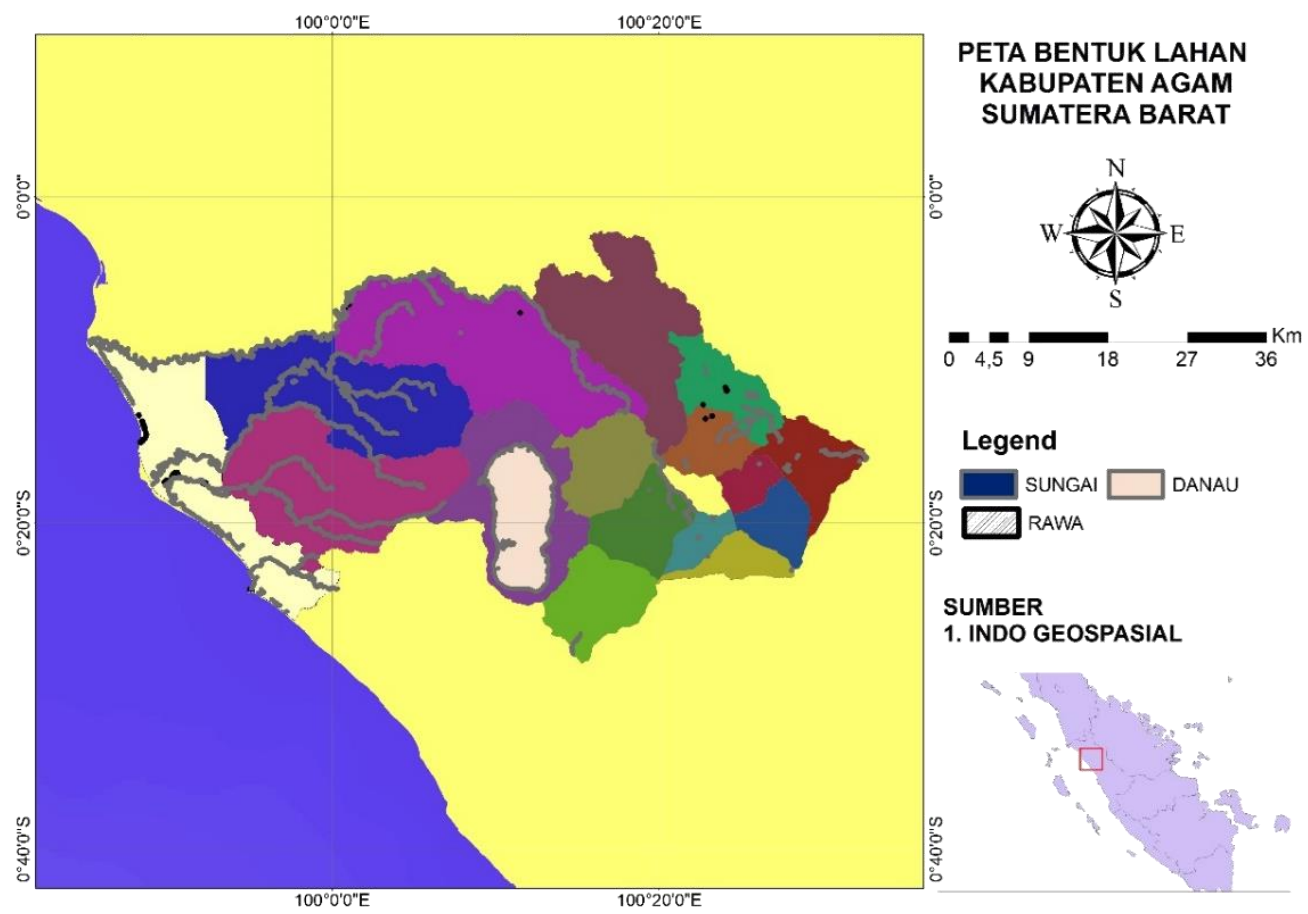

Gambar 7. Peta Bentuk Lahan di kabupaten Agam yang terdiri dari tutupan lahan berupa sungai, rawa, danau.

\section{HASIL DAN PEMBAHASAN}

\subsection{Penutupan Lahan}

Penutupan lahan yang didapatkan pada wilayah Kabupaten Agam, Sumatera Barat. Pada citra
Landsat yang digunakan yaitu citra saat musim hujan dengan kondisi awan yang paling minimum. Interpretasi citra Landsat menghasilkan peta penutupan lahan seperti terlihat pada Gambar 8. Peta penutupan lahan Kabupaten Agam, Sumatera Barat

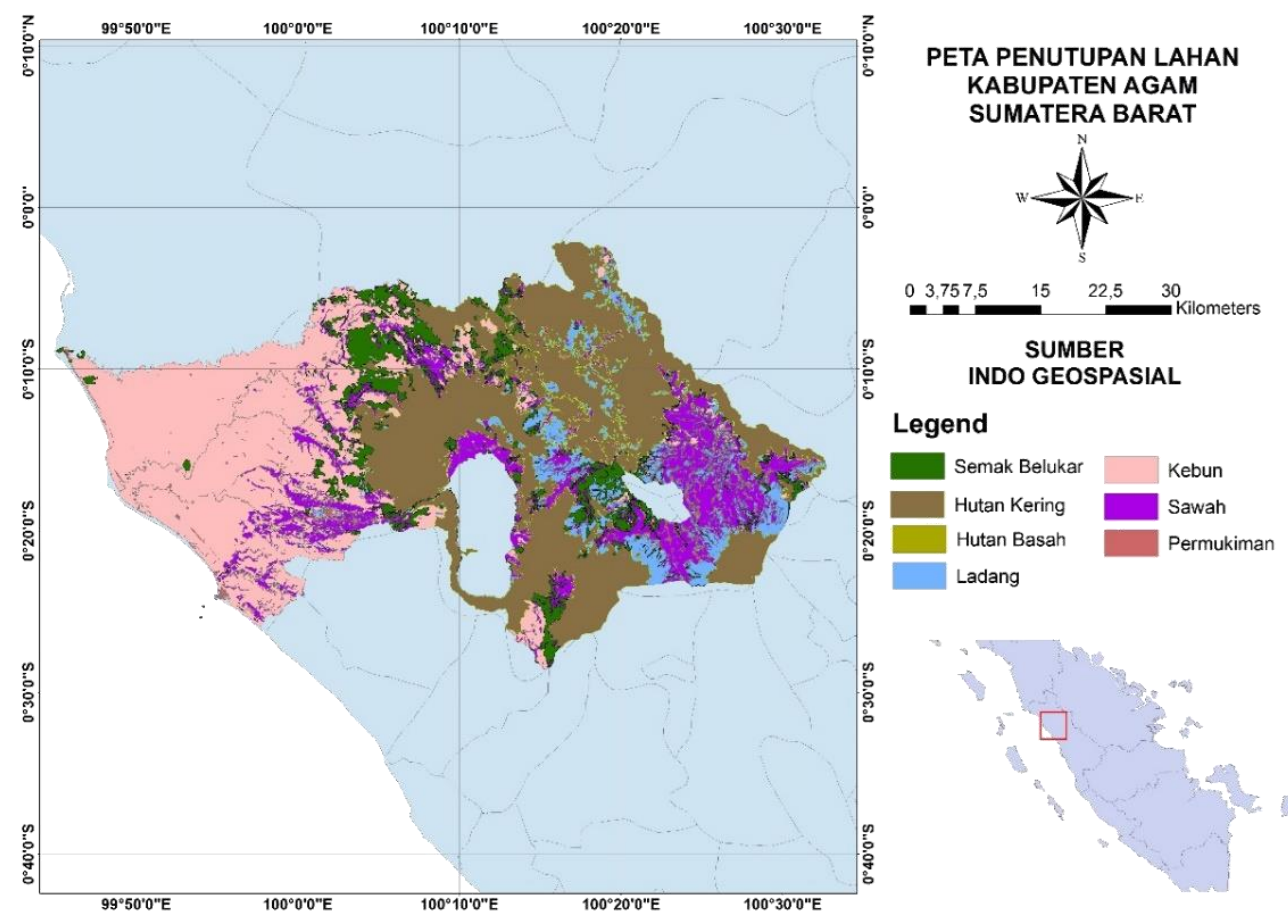

Gambar 8. Peta Penutupan Lahan Kabupaten Agam yang terdiri dari 7 bagian penutup lahan yaitu Semak Belukar, Hutan Kering, Hutan Basah, Ladang, Kebun, Sawah dan Permukiman.

yaitu terdiri dari Semak Belukar, Hutan Kering, mukiman. Pada peta penutupan lahan ini mengHutan Basah, Ladang, Kebun, Sawah dan Per- gunakan sumber dari data citra Landsat. 


\subsection{Curah Hujan}

Pada peta kelas curah hujan yang telah dibuat yaitu peta curah hujan rata-rata tahunan dan peta curah hujan rata-rata bulanan di mana terjadi yaitu tiga bulan puncak selama musim hujan. Adapun temperatur udara yang terdapat pada wilayah Kabupaten Agam terdiri dari dua macam, yaitu di daerah dataran rendah dengan temperatur minimum yaitu $250^{\circ} \mathrm{C}$ dan maksimum yaitu $330^{\circ} \mathrm{C}$ terdapat pada Lubuk Basung, sedangkan pada daerah tinggi yaitu minimum pada temperatur $200^{\circ} \mathrm{C}$ dan maksimum $290^{\circ} \mathrm{C}$ terdapat pada Tilatang Kamang. Kemudian, kelembaban udara rata-rata $88 \%$, kecepatan angin yaitu antara $4-20$ $\mathrm{Km} / \mathrm{jam}$
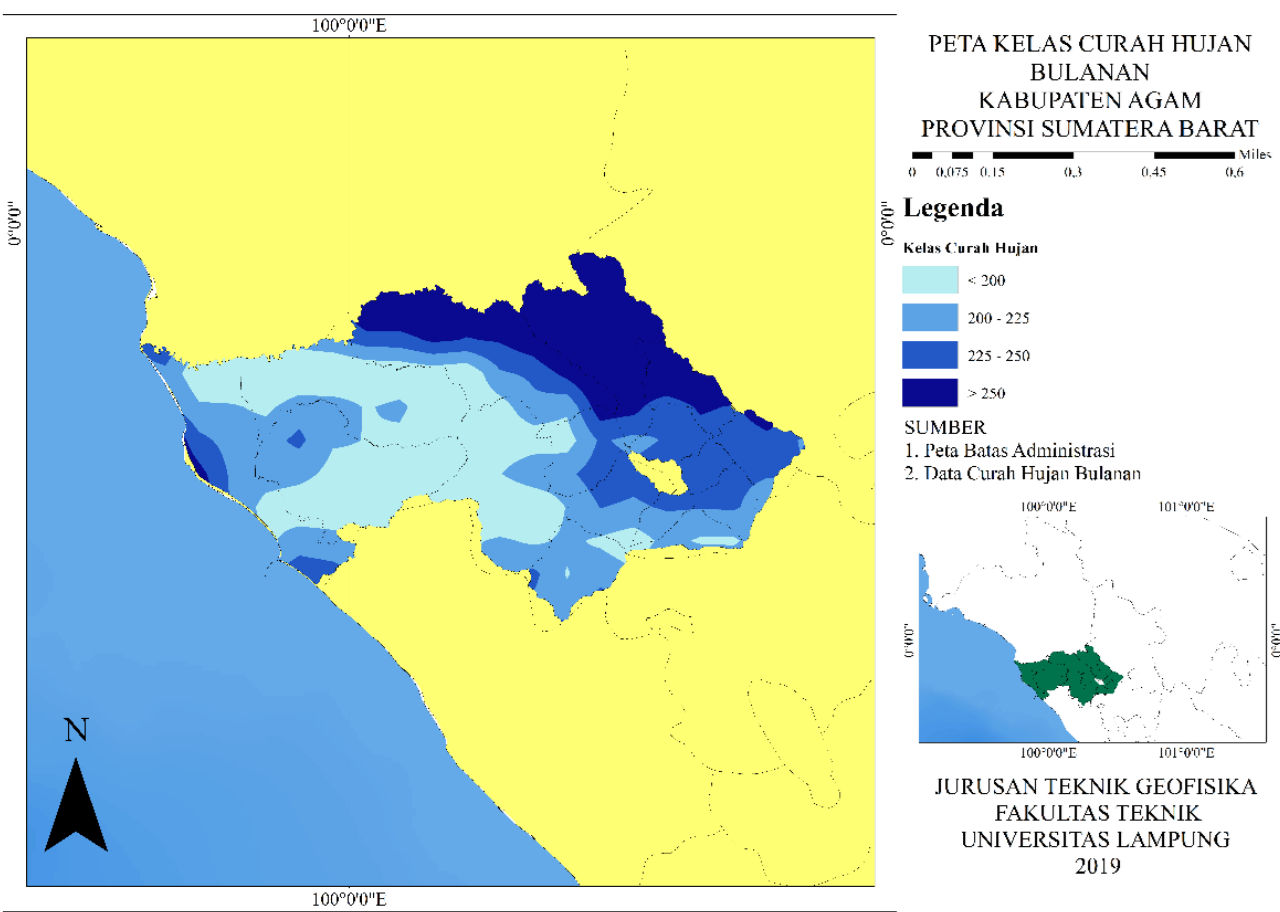

Gambar 9. Curah hujan bulanan yang diklasifikasikan menjadi 4 kelas curah hujan, yaitu daerah dengan curah hujan > $200 \mathrm{~mm} / \mathrm{tahun}$, daerah dengan curah hujan 200-225 mm/tahun, daerah dengan curah hujan $225-250 \mathrm{~mm} / \mathrm{tahun}$ dan daerah dengan curah hujan >250 mm/tahun

serta penyinaran matahari rata-rata $58 \%$ (Rakhman, 2015).

Tabel 2. Pembobotan curah hujan bulanan yang diklasifikasikan menjadi 4 kelas curah hujan yaitu pada kelas $<200$ dengan $28,07 \%$, kelas $200-225$ dengan $22,36 \%$, kelas $225-250$ dengan $9,45 \%$, kelas $>250$ dengan $15,16 \%$

\begin{tabular}{lll}
\hline No & Kelas & Persen \\
\hline 1 & $<200 \mathrm{~mm}$ & $28,07 \%$ \\
2 & $200 \mathrm{~mm}-225 \mathrm{~mm}$ & $22,36 \%$ \\
3 & $225 \mathrm{~mm}-250 \mathrm{~mm}$ & $9,45 \%$ \\
4 & $>250 \mathrm{~mm}$ & $15,16 \%$ \\
\hline
\end{tabular}

Adapun musim hujan pada wilayah Kabupaten Agam, Sumatera Barat yaitu terjadi pada bulan Januari sampai dengan bulan Mei dan bulan September sampai bulan Desember, sedangkan untuk musim kemarau berlangsung antara bulan Juni sampai dengan bulan Agustus. Pada Kabu- paten Agam, Sumatera Barat memiliki 4 kelas curah hujan, yaitu sebagai berikut. Pada daerah dengan curah hujan yaitu $>200 \mathrm{~mm} /$ tahun tanpa bulan kering merupakan daerah dengan iklim yaitu Tipe $A$, yang berada di sekitar lereng gunung Merapi Singgalang serta meliputi sebagian wilayah Kecamatan IV Koto dan Sungai Pua (Fahrizal, 2014).

Pada daerah dengan curah hujan yaitu 200-225 $\mathrm{mm} /$ tahun tanpa bulan kering yaitu merupakan daerah dengan tipe A1 yang mencakup sebagian wilayah Kecamatan Tilatang Kamang, Baso dan Ampek Angkek. Pada Daerah curah hujan yaitu sekitar 225-50 mm per tahun dengan bulan kering selama 1 sampai dengan 2 bulan berturut-turut yaitu yang meliputi sebagian Kecamatan Palembayan, Palupuh, serta pada IV Koto (Matondang, J.P. 2013). Selanjutnya, daerah dengan curah hujan yaitu lebih dari $250 \mathrm{~mm}$ per tahun pada bulan kering selama 1 sampai dengan 2 bulan selama berturut, yaitu yang meliputi sebagian wilayah Kecamatan Lubuk Basung serta di Tanjung Raya. 

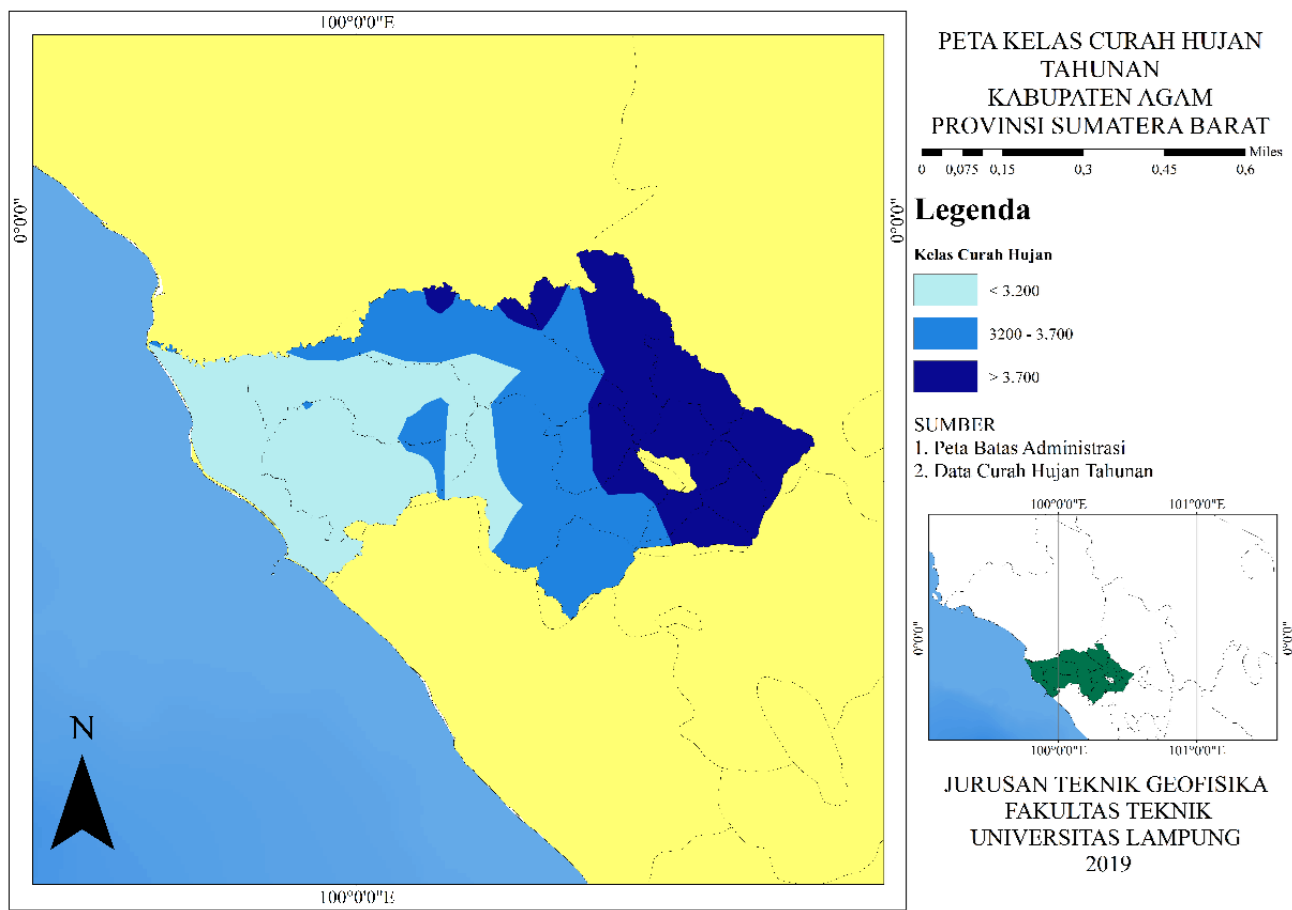

Gambar 10. Curah hujan tahunan yang diklasifikasikan menjadi 3 kelas curah hujan yaitu kelas $>3200$ dengan $47,05 \%$, kelas $3200-3700$ dengan $23,84 \%$, dan kelas $>3700$ dengan $29,11 \%$

Tabel 3. Pembobotan curah hujan tahunan yang diklasifikasikan menjadi 3 kelas curah hujan yaitu kelas $>3200$ dengan $47,05 \%$, kelas $3200-3700$ dengan $23,84 \%$, dan kelas $>3700$ dengan $29,11 \%$

\begin{tabular}{lll}
\hline No & \multicolumn{1}{c}{ Kelas } & \multicolumn{1}{c}{ Persen } \\
\hline 1 & $>3200 \mathrm{~mm}$ & $47,05 \%$ \\
2 & $3200-3700 \mathrm{~mm}$ & $23,84 \%$ \\
3 & $<3700 \mathrm{~mm}$ & $29,11 \%$ \\
\hline
\end{tabular}

\subsection{Karakteristik pada Wilayah Rawan Banjir dan Peta Rawan Banjir}

Pada peta rawan banjir yang telah kami buat, yaitu menampilkan mengenai informasi tentang sebaran kelas daerah rawan banjir pada wilayah pengamatan. Kemudian, pada daerah rawan banjir adalah daerah yang dari segi fisik dan klimatologi yang memiliki kemungkinan terjadi banjir. Pada
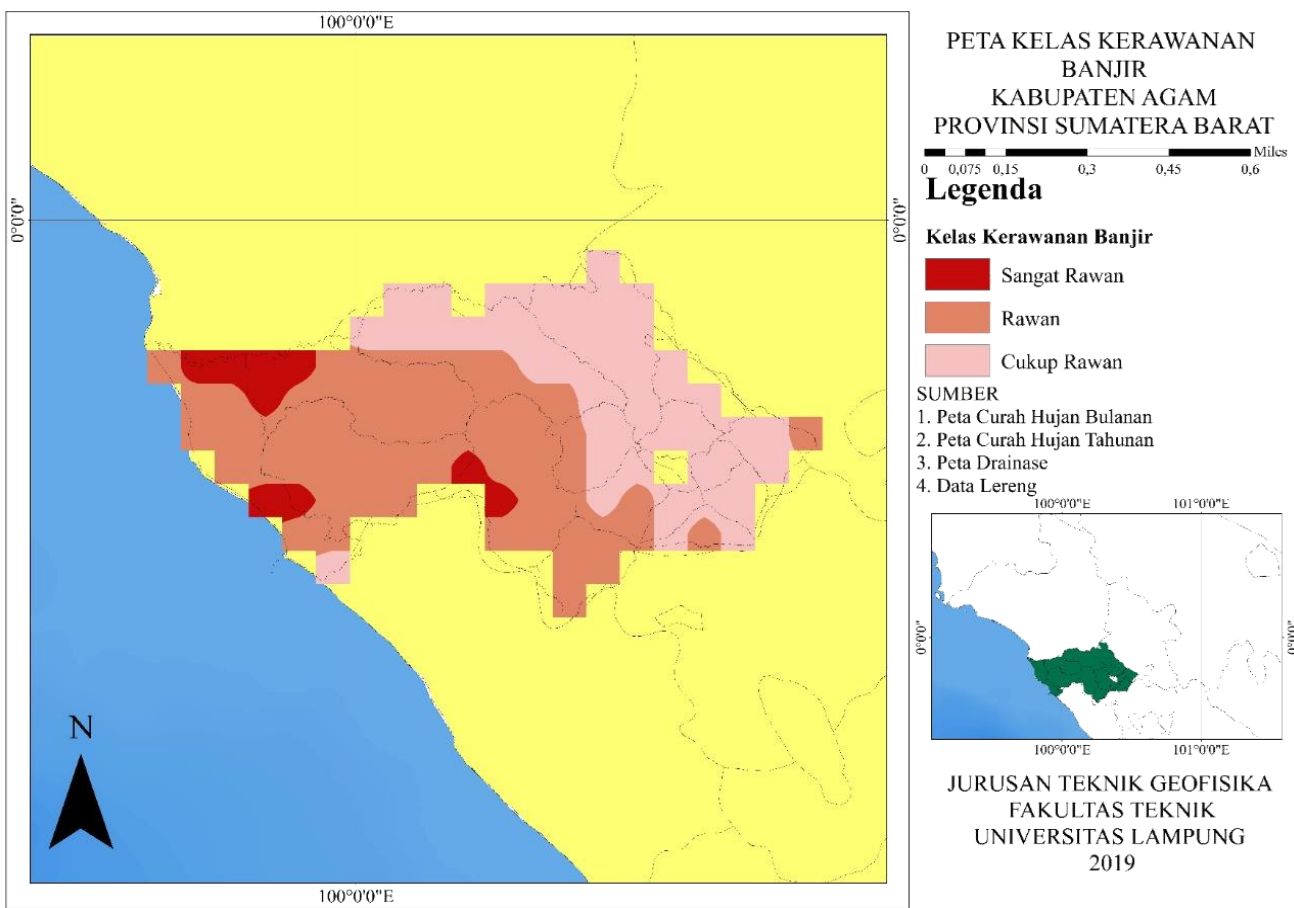

Gambar 11. Peta rawan banjir yang dikategorikan menjadi 3 bagian, yaitu daerah sangat rawan terdapat pada pinggir pantai, rawan dan cukup rawan yang berada jauh pada pinggir pantai atau berada di daratan. 
peta rawan banjir yaitu yang diperoleh dari tumpang susun peta-peta dari parameter pada rawan banjir. Adapun parameter banjir yang digunakan yaitu curah hujan, kemiringan lereng, bentuk lahan, penggunaan lahan, dan drainase, serta buffer sungai. Pada parameter curah hujan ini dibagi menjadi kelompok dengan kelas curah hujan ratarata tahunan serta dengan curah hujan rata-rata bulanan, kemudian kelompok pembobotan pada penelitian ini dibedakan menjadi dua.

\section{KESIMPULAN}

Daerah yang kami amati adalah kabupaten Agam yang terletak di Sumatera Barat dan memiliki luas daerah 2.232,30 $\mathrm{Km}^{2}$ atau (5,29\%) dari seluruh luas total wilayah provinsi Sumatera Barat. Kabupaten agam sendiri memiliki kondisi topografi yang cukup bervariasi seperti ketinggian dan kemiringan. Dan daerah ini merupakan daerah yang dapat dikategorikan sebagai daerah yang rawan banjir dikarenakan memiliki intensitas ratarata hujan yang cukup tinggi pada wilayah timur dan wilayah tersebut memiliki bentuk lahan dan penutupan lahan yang tidak mendukung, hal ini juga didukung dengan topografi daerah kabupaten Agam yang didominasi oleh daratan yang curam, dan lebih dari 50\% wilayah kabupaten Agam, Sumatera Barat memiliki drainase yang sangat buruk sehingga jika hujan turun dengan debit yang besar dan penyaluran air kurang baik atau tidak ada hal ini dapat menyebabkan banjir.

Untuk setiap peta menggunakan metode yang berbeda-beda seperti pada peta curah hujan yang mana peta ini menggunakan dua metode yaitu metode thiessen polygon dan isohyet yang mana kedua metode ini memiliki kegunaan yang berbeda yang dapat menentukan kelas curah hujan bulanan dan tahunan di kabupaten Agam, Sumatera Barat.

\section{UCAPAN TERIMA KASIH}

Diucapkan terima kasih kepada semua pihak yang telah berkontribusi dalam pembuatan artikel ini, sehingga artikel ini dapat selesai dengan baik. Terutama kepada dosen pembimbing dalam pembuatan artikel ini.

\section{DAFTAR PUSTAKA}

Aditya, T. (2010). Visualisasi Resiko Bencana di Atas Peta. Yogjakarta: Fakultas Teknik Geodesi Universitas Gadjah Mada

Andini, W. S., Prasetyo, Y., \& Sukmono, A. (2018). Analisis Sebaran Vegetasi Dengan Citra Satelit Sentinel Menggunakan Metode NDVI dan Segmentasi. Jurnal Geodesi Undip, 7, 1424.
BNBP. (2012). Peraturan Kepala Badan Nasional Penanggulangan Bencana Nomor 2 Tahun 2012 Tentang Pedoman Umum Pengkajian Risiko Bencana. Jakarta: BNPB.

Utama, E. (2013). Modul Pelatihan ArcGIS 10.1. Bandung: ITB.

Fahrizal, R. (2014). Analisis Spasial untuk Menentukan Zonasi Banjir Bandang (Studi Kasus: Kabupaten Sinjai). Prosiding Seminar Nasional Geofisika 2014, 109-113.

Matondang, J. P. (2013). Analisis Zonasi Daerah Rentan Banjir Dengan Pemanfaatan Sistem Informasi Geografis (Studi Kasus: Kota Kendal dan Sekitarnya). Skripsi. Program Studi Teknik Geodesi Universitas Diponegoro; Semarang.

Nugraha, A. L. (2013). Penyusunan dan Penyajian Peta Online Risiko Bencana Banjir Rob Kota Semarang. Tesis. Teknik Geomatika Universitas Gajah Mada.

Nurhamidah, van de Giesen, N., \& Hoes, O. (2011). Subsidence and Deforestation: Implications for Flooding in Delta's Southeast and East Asia. Proceeding of the International Conference on Advanced Science, Engineer-ing and Information Technology, 658-663.

Nurjanah, Sugiharto, R., Kuswanda, D., Siswanto, B. P., \& Adikoesoemo. (2012). Manajemen Bencana. Yogyakarta: Alfabeta.

Pangaribuan, J., Sabri, L. M., \& Amarrohman, F. J. (2019). Analisis Daerah Rawan Bencana Tanah Longsor di Kabupaten Magelang Menggunakan Sistem Informasi Geografis Dengan Metode Standar Nasional Indonesia dan Analythical Hierarchy Process. Jurnal Geologi Undip. 8(1), 890

Rakhman, A. A. (2015). Aplikasi Penginderaan Jauh dan Sistem Informasi Geografi untuk Pemetaan Zonasi Banjir di Kabupaten Lamongan. Tugas Akhir. D3 Penginderaan Jauh dan Sistem Infromasi Geografi, UGM.

Santosa, W. W., Suprayogi, A., \& Sudarsono, B. (2015). Kajian Pemetaan Tingkat Kerawanan Banjie dengan Menggunakan Sistem Informasi Geografis (Studi Kasus: DAS Beringin, Kota Semarang). Jurnal Geodesi, 4(2), 185-190.

Subdibyakto, H.A. (2011). Manajemen Bencana Di Indonesia Kemana. Yogyakarta: Gadjah Mada University Press.

Suprapto. (2011). Statistik Pemodelan Bencana Banjir Indonesia (Kejadian 2002-2010). Jakarta: BNPB.

Tim Penyusun BNPB. (2012). Tanggap Tangkas Tangguh Menghadapi Bencana. Jakarta: BNPB. 